\title{
STUDIES ON THE MAMMARY GLAND
}

III. A COMPARISON OF THE DEVELOPING MAMMARY GLANDS IN MALE AND FEMALE ALBINO RATS FROM THE LATE FETAL STAGES TO TEN WEEKS OF AGE

\section{J. A. MYERS}

Institute of Anatomy, University of Minnesota, Minneapolis

SEVEN FIGURES

Schickele ('99) while studying the development, arrangement, and variation of the mammary glands in rats noticed that ordinarily macroscopic examinations do not reveal nipples in males.

In his work on the recognition of sex through external characters in the young rat, Jackson ('12) called attention to the fact that the mammary gland nipples become very conspicuous in female rats of about two weeks (post-natal life) while in male rats of the same age there is no external indication of nipples. The difference between the two sexes in this respect is so marked that he could readily distinguish the sexes at that age by the use of this single external character.

Steinach ('12) made successful reciprocal transplantations of testes and ovaries in young male and female guinea pigs. The males in which the ovaries grew gradually assumed the appearance of females even to such an extent that some of them developed functional mammary glands. The same experiments were applied to rats, and from these experiments Steinach reached the following conclusion: "Das Rattenmänchen ist für diesen Punkt des Untersuchen deshalb ungeeignet, weil bei ihm diese Anlagen nicht einmal rudimentär ausgeprägt, bzw.makroskopisch nicht sichtbar sind." 
My studies (Myers, '16), which were confined entirely to the mammary glands of the female albino rat, led later to a careful macroscopic search for nipples in males of corresponding ages. No trace of nipples was found in any male individual.

The above observations made by four different workers are somewhat contradictory to the usual view that the mammary glands of male animals are parallel in their development with those of females until the stage of puberty, at which time the glands of the male stop growing and later atrophy, while those of the female undergo a very rapid development. In view of such an apparent discrepancy the present work was undertaken. A brief abstract of the results has already been published (Myers, '17 a).

\section{MATERIAL AND TECHNIQUE}

The fetuses for this work were collected, fixed, sectioned and stained in the same manner as the female fetuses described in an earlier paper (Myers, '17 b). Cleared preparations were made according to the method described by Lane-Claypon and Starling ('06).

In making macroscopic examinations it was very desirable to have the hair removed from the skin. At first a sharp razor was used to shave the abdominal wall. This method was later discarded, however, and the hair was removed from the entire body with sodium sulphide as suggested by Frank and Unger ('11).

Some of the litters used for this study were slightly under normal weight. Therefore in each case it became necessary to compare males and females of the same litter. In this manner it was possible to compare individuals of the same age and of approximately the same gross body weight.

In all, 70 individuals were examined, makng a total of approximately 840 mammary glands. About one-half of the entire number of individuals were fetuses. The remaining 35 were fairly evenly distributed among the described post-natal stages ranging from birth to ten weeks of age. 


\section{OBSERVATIONS}

Fifteen and sixteen days. At fifteen days and nine hours the sex glands of the fetuses are in the indifferent stage. In the fetuses of sixteen days and twelve hours the sex glands are so differentiated that with considerable difficulty the sexes can be distinguished. In the last mentioned stage there is no apparent difference between the developing mammary glands of the two sexes. Therefore the description of the mammary glands of both of the above stages given in a previous paper (Myers, '17 b) is applicable to either sex.

Eighteen days. In male fetuses of eighteen days and nine hours fresh preparations show the epidermis over each developing mammary gland to be somewhat lighter than the adjacent epidermis. The epidermis is in most cases elevated so as to form a slight eminence. In one instance, however, a very shallow mammary pit was observed over a single gland.

In females of this age, it will be recalled, the area over the developing mammary gland appears lighter than the adjacent region, but instead of an eminence there is usually a distinct mammary pit present over the developing mammary gland.

The stratum germinativum and basement membrane of the epidermis in the region surrounding the developing primary duct, become continuous with the duct and form the peripheral layer of cells and basement membrane of the duct respectively. The primary duct passes through the corium into the tela subcutanea, as was found to be the case in the female. At this stage the primary duct somewhat resembles a large developing hajr (fig 1). At its free end is seen a considerable expansion which may give off one or two small buds. The mesenchyma forms a thick condensed layer around the duct.

The primary duct of the female in size and general form is similar to the duct of the male; however, it does not show such a marked expansion at its free end. Its attached end also lies deeper from the surface of the epidermis, owing to the fact that it springs from the bottom of the developing mammary pit. The layer of condensed mesenchyma surrounding the primary duct is thinner than in the male. 


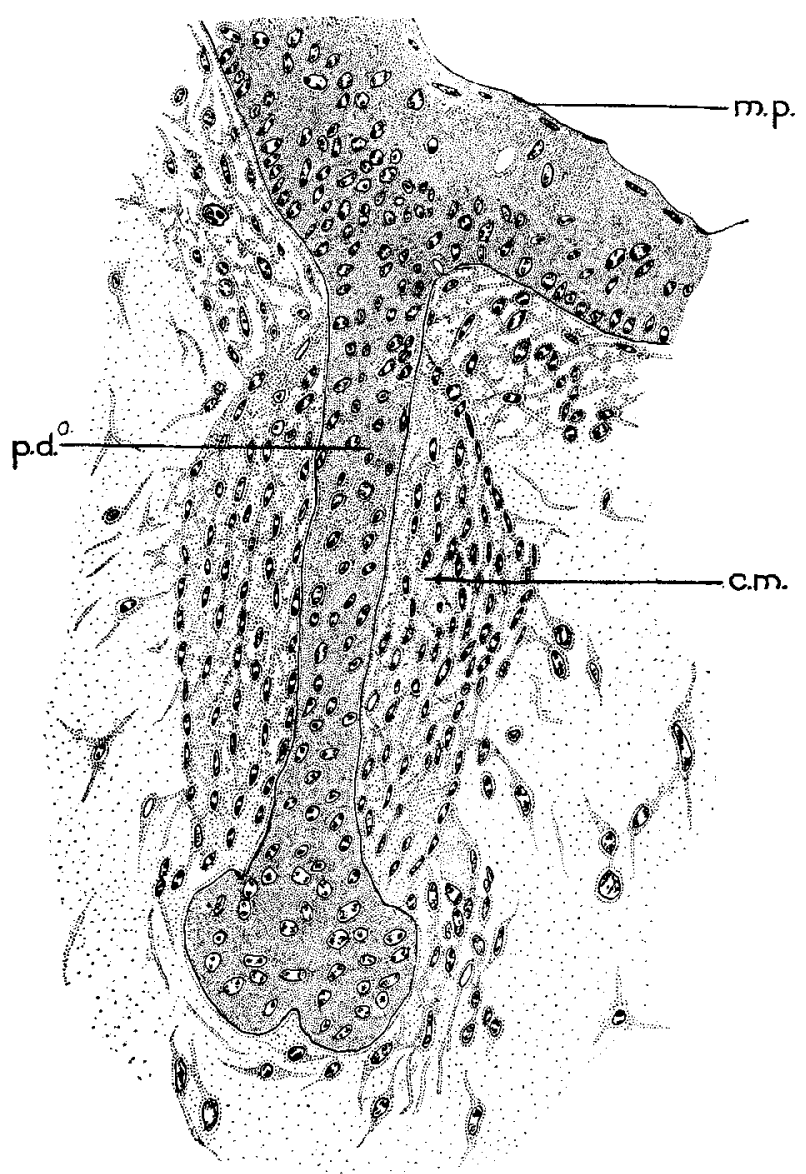

Fig. 1 Drawn from a section through the left third thoracic developing mammary gland of a male albino rat fetus of eighteen days and nine hours. $\times 300$. Zenker's fixation; haematoxylin-eosin stain. Drawn with the aid of a camera Iucida. Comparing this figure with figure 2 of an earlier paper (Myers, ' $17 \mathrm{~b})$ for the female, note the difference in appearance of the primary ducts (p.d.). The condensed mesenchyma (c.m.) immediately surrounding the primary duct is thicker in the male sex. There is less indication of a developing mammary pit (m.p.) in the male gland. 
Nineteen days. When studied with a dissecting microscope, most of the mammary glands of nineteen day and six hour fetuses are not visible on the surface of the integument. An occasional gland, however, is represented, as in the preceding stage, by an area of epidermis slightly lighter in appearance in fresh preparations than the adjacent epidermis.

The glands of the females of this stage are very conspicuous from the surface. In the female, the gland areas are very light in appearance and a well developed mammary pit is located in the center of each area.

The primary duct (of the male) at this stage has lost its resemblance to a developing hair. The attachment of the duct to the epidermis, however, is not unlike that of a developing hair. As the primary duct approaches the deep surface of the epidermis, its basement membrane and peripheral layer of cells are seen to be continuous with the same structures of the skin. The attachment of the duct is, therefore, very near the surface. As in females of the same age, the primary duct passes into the tela subcutanea where it turns at right angles and courses parallel to the surface of the integument. Considerable variation is exhibited in the branching of the ducts. In some glands tertiary ducts are terminal while in others the primary duct is the terminal duct at this age.

The lumina develop in the same manner as reported for the female (Myers, '17 b). In general it may be said, however, that the lumina of the male mammary ducts at this stage are apparently somewhat further developed than those of females.

The stratum germinativum surrounding the attached end of the primary duct is somewhat thickened thus forming a slight ridge around the attachments of the duct. This ridge suggests the epithelial hood anlage, which is distinctly in evidence in females at this time.

The developing connective tissue of the male gland corresponds in structure and arrangement with that of the female.

Twenty days. At twenty days and six hours there is neither eminenoe nor mammary pit over the male mammary gland area in fresh specimens. The epidermis of the area is no longer 


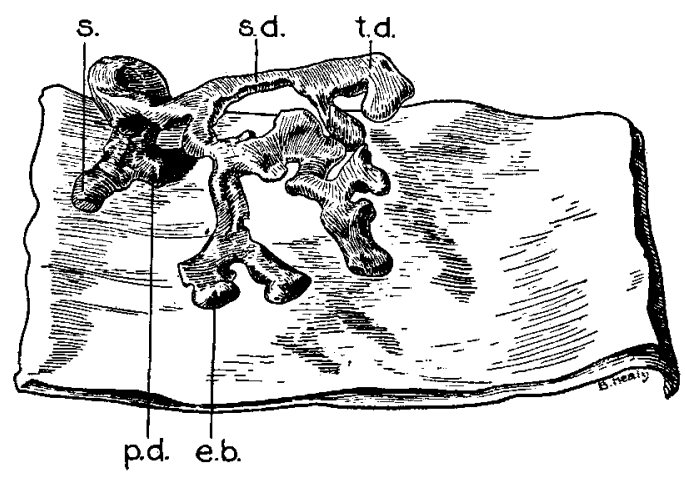

Fig. 2 Internal view of a wax model reconstructed from the left first inguinal gland of a male albino rat fetus of twenty days and six hours. $\times 50$. When compared with figure 12 of a previous paper (Myers, '17 b) note the absence of an epithelial ingrowth (ep.in.) and the presence of a short branch (s.) arising from the primary duct near its attached end in the male. The structures listed below are approximately the same in both sexes. e.b., end bud; p.d., primary duct; s.d., secondary duct; t.d., tertiary duct.

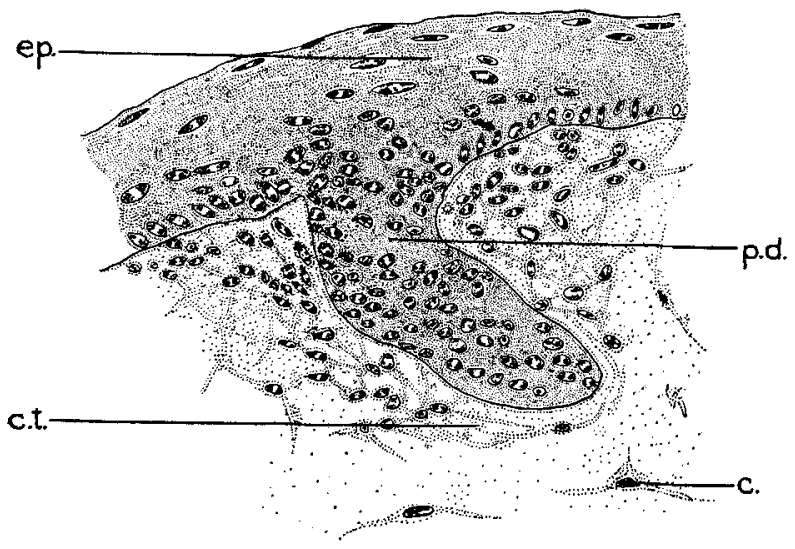

Fig. 3 Drawing of a section through the left abdominal gland of a male newborn albino rat. $\times 300$. Zenker's fixation; haematoxylin-eosin stain. Note the entire absence of nipple, mammary pit, and epithelial hood. Other parts similar to those of the female. c., irregularly arranged connective tissue cells; c.t., connective tissue forming sheath around duct; ep., epidermis; p.d., primary duct. 
lighter than the adjacent epidermis. There is therefore no external indication of a developing mammary gland in the male rat at this stage. As previously shown (Myers, '17 b), the glands in the female are now quite conspicuous. They are distinctly visible with the naked eye. In sections, the female gland shows a distinct mammary pit with the nipple anlage at the bottom of the pit.

The primary duct in the male near its attachment to the epidermis is often seen to give off a short solid branch (fig. 2), which was not observed on the female duct. In some instances there appear more divisions of the milk ducts than have been observed in females of the same age. The second inguinal gland has failed to develop as rapidly as the others. It therefore appears somewhat rudimentary.

The lumina correspond to those described in the female, except that they are slightly larger in the male.

Hair follicles are developing in the immediate neighborhood of the attachment of the primary duct. This is contrary to the condition in the female, where hair follicles were not observed at this stage in or close around the mammary pit.

The epithelial hood anlages do not appear in the male at this age.

Newborn. At birth, as in the twenty day stage, all external appearances of mammary glands are lacking in the male. At this time the glands of the female may be observed with the unaided eye in living and fresh specimens as light areas in the positions of the future nipples.

Microscopic sections likewise do not reveal even the slightest trace of a nipple or an epithelial hood in the male at this time. In the female, however, the nipple almost fills the mammary pit and the epithelial hood is well formed.

The primary duct attaches to the deep surface of the epidermis, but does not reach the outer surface of the body. Leaving the epidermis, the duct passes deeply through the corium into the tela subcutanea where it turns at right angles, passes parallel to the surface of the skin and presents secondary ducts. Immediately beneath the corium the primary duct gives off a 
short branch (as in the preceding stage) which courses parallel with the surface. No similar branch was observed in females. The ducts at this stage, including representatives of secondary, tertiary, quaternary, etc., present the same general appearance and the same method of branching as those found in females. The second inguinal gland, however, is an exception as it is still very rudimentary.

A continuous lumen is present in each system of ducts observed. The lumen of the primary duct, however, does not extend as far as the attached end of the duct. The short branch of the primary duct immediately subjacent to the corium likewise
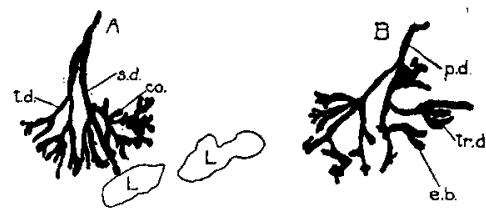

Fig. 4 Drawn from a cleared preparation (internal view) of a male albino rat one week after birth (body weight 8 grams) to show distribution and relations of ducts of right abdominal gland $(A)$; and right first inguinal gland $(B) . \quad \times 5$. The second inguinal glands were absent in this specimen. Nipples and epithelial hoods are absent. Otherwise the glands of the two sexes are similar in their development. Compare this figure with figure 7 of an earlier paper (Myers, '16, p. 379). L., lymph node; p.d., primary duct; s.d., secondary duct; $t . d$. , tertiary duct; tr.d., terminal duct; e.b., end bud; co., collateral duct.

possesses a lumen. The lumina, like those of the female at this age, have not reached their definitive stage of development.

One week. One week after birth the milk ducts of the glands in males apparently do not present many more branches than at the time of birth. The glands occupy the same positions as those of females and the branching has reached approximately the same stage (fig. 4). The only exception to this statement is found in the second inguinal gland. This gland has become so rudimentary that it sometimes fails to appear in cleared preparations. When it is present it presents a very small number of branches.

Two weeks. At the end of the second week in each of the first thoracic glands in males its duct is seen to extend cephalad 
from its attachment to the epidermis. No branches were observed to take a caudal direction, as is the case in the female. The ducts of the second and third thoracic glands take a more. lateral direction and are fully as well developed as those of females. In the abdominal and first inguinal glands a few lateral buds are seen on the main ducts. The ducts of corresponding glands of the females show a large number of such buds. The second inguinal gland when visible in cleared preparations presents a primary duct which courses caudad. Its branches are very few. At the free ends of the ducts of all glands at this stage are found growing end buds, as were previously described in the female.

Three and four weeks. At three weeks the glands show very little increase in development over the two weeks stage. The glands of four weeks' male rats, however, show further development. Each of the first thoracic glands presents a larger number of branching ducts, the majority of which are directed cephalad from the point of surface attachment. A few branches, however, take a caudal direction as was found to be the case in females in younger stages. The ducts of the second and third thoracic glands have sent out several collateral branches which in some individuals nearly obliterate the space between the ducts of these glands. The abdominal glands now present a large number of lateral buds which, as in females, are not so numerous on the primary and secondary ducts as on the tertiary, quaternary and terminal ducts. In the male rat, the first inguinal gland of one side is occasionally lacking. Frequently the second inguinal glands are absent. Neither the first nor the second inguinal glands are absent in any female observed. It is not uncommon, however, to find the second or third thoracic gland undeveloped in either sex.

Five weeks. It will be recalled that at the fifth week the glands of the female were observed to develop very rapidly (Myers, (16). The ducts are much longer than in previous stages. Many new branches spring from the more distal ducts of the glands. The interval between the ducts of the second and third thoracic glands has largely disappeared on both sides, there being a 
slight overlapping of the ducts. The ducts of the abdominal and first inguinal glands likewise overlap, thus obliterating the interval between these two glands. Furthermore some of the ducts of the second inguinal gland have grown cephalad, have met and overlapped the caudally directed ducts of the first inguinal. The ducts of the second inguinal gland branch very profusely.

At this stage the mammary glands of the male have failed to keep pace with the rapid development of the glands of the female. While in some individuals the ducts of the second and third thoracic glands are nearly in apposition, there still exists a definite interval in most cases. There are likewise very marked intervals between the abdominal and first inguinal and the first and second inguinal glands. The second inguinal gland shows no progress in development over the preceding stages. Not only are the milk ducts of the male shorter in length, but they are less numerous than those of the female.

Six, seven and eight weeks. At six, seven and eight weeks the differences between the male and female glands are becoming still more obvious. The most noticeable difference is the absence or very rudimentary condition of the second inguinal gland of the male. A mere glance at any of the remaining glands will enable the observer to distinguish between male and female. The most prominent distinguishing character is the large number of collateral ducts that have grown from the chief milk ducts in the female. The collaterals have branched and each terminal branch presents a large end bud. In the males a much smaller number of collaterals appear. Thus the arborization of the male gland is much less dense. In no case have the ducts of two adjacent glands in the male overlapped so as to form a continuous mass of gland tissue.

Nine and ten weeks. In an earlier study (Myers, '16), it was shown that the mammary glands of female rats show a tremendous increase in growth and development about the ninth or tenth week. The overlapping of the ducts of the thoracic glands is so extensive that a continuous mass of gland tissue extends from the cephalic ends of the ducts of the first thoracic gland to 
the caudal ends of the ducts of the third thoracic glands. No complete intervals exist between the glands. Furthermore ducts from each of the first thoracic glands have grown so near the mid-line that only a small space now separates them. A considerable space exists between the last thoracic and abdominal glands. The ducts of the abdominal and first and second inguinal glands also overlap so as to form one continuous mass of gland tissue, extending from the most cephalic of the ducts of the abdominal gland to a point somewhat caudad to the genital orifice. Medial branches of the second inguinal gland, extending near the mid-line, nearly surround the vagina.

A comparison of figure 5 with figure 13 of an earlier paper (Myers, '16, p. 385) shows that in male rats of nine and ten weeks there is no progressive development of the mammary glands corresponding to that just described in females. In figure 5, the second inguinal gland is seen to present very few branches, thus offering a marked contrast with the same gland of the female. In most of the individuals examined, cleared preparations failed to reveal the presence of the second inguinal gland. The first inguinal and abdominal glands are separated by a definite space, there being no overlapping. It should be mentioned, however, that in one male of nine weeks the ducts of the first inguinal and abdominal glands were found to present a rather dense arborization. The ducts of the two glands in this case overlap to some extent. Even in this individual, which apparently represents an unusual variation, the glands are still distinctly less extensively developed than in the females of corresponding age.

Microscopic sections reveal large lumina in the milk ducts of the male. As was found in females, the end buds now possess somewhat larger lumina than the ducts into which they open. The primary duct when traced toward the surface of the body is seen to pass from the tela subcutanea into the corium where it makes a very oblique angle with the surface. Before reaching the surface, however, the lumen is seen to end in the duct within the corium in all glands studied at this stage. In one case the primary duct ended in very close relation to the at- 
tached end of a hair follicle. The lumen of the duct could not be traced into the hair follicle, but the relation of the duct to the hair follicle is strongly suggestive of that existing in lower forms of mammals.
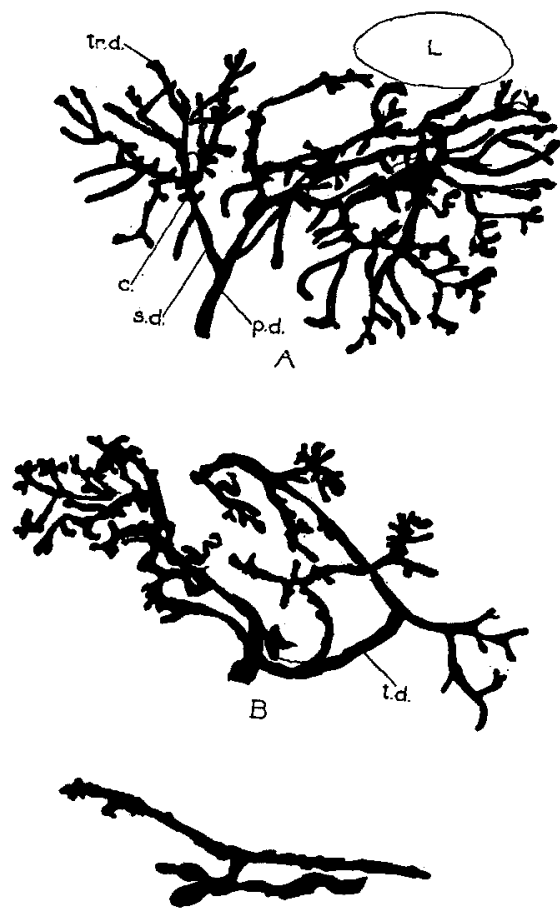

C

Fig. 5 Drawn from a cleared preparation (internal view) of a male albino rat nine weeks old (body weight 95 grams).$\times 5$. Compare this figure with figure 13 of an earlier paper (Myers, '16), p. 385), showing the much more extensive and complicated branching of the ducts in the female of corresponding age. $A$., left abdominal gland; $B$., left first inguinal gland; $C$, rudimentary left second inguinal gland. The drawings do not represent the glands in their natural spatial position with reference to each other.

It is interesting to note that in several of the postnatal stages studied it was possible to obtain a few individuals of approximately the same age whose gross body weight was somewhat above or below the normal for that age. In general it may be said that in both sexes the mammary glands correspond somewhat 
with the gross body weight of the animal, i.e., in those individuals noticeably under weight the glands are somewhat smaller than in those of normal and above normal weight. When the body weight is far below normal the glands of the female do not show such a dense arborization at the age when puberty normally appears. Perhaps this is due to the fact that the arrival of puberty is slightly delayed.

A few male rats between the ages of ten and sixteen weeks were examined. In all observations made the glands of the sixteen week rats were found somewhat better developed than in those of nine and ten weeks. Apparently considerable growth has taken place and new ducts have developed as the arborization of ducts appears more dense.

\section{DISCUSSION AND CONCLUSIONS}

The nipple

In the fetus at eighteen days in the male albino rat the surface of the future nipple area appears somewhat lighter than the surrounding epidermis. It is very rare to find a developing mammary pit in the male at this time. In nineteen day male fetuses an occasional gland can be recognized from the surface, but with difficulty, while at twenty days there is no external indication of the mammary glands in the male. About two weeks after birth, when the nipples of the female become so conspicuous owing to the lack of hair around the nipples (Jackson, '12) and to the very rapid growth of the nipple itself (Myers, '16), there is no trace of a nipple in the male. The hair develops quite uniformly over the entire abdominal and thoracic wall. From this stage through the ten weeks stage no nipples were observed in any of the male individuals studied (cf. figs. 6 and 7). Microscopic examinations of all stages likewise show the absence of nipples.

The absence of nipples in the male rats is contrasted with their presence as observed by many workers in a large number of animal species, including man. While the nipples of men are rudimentary, they are absent only in anomalous cases. 
It is a well known fact that rudimentary nipples also appear in the males of many of our domestic animals. According to Schickele, Eschricht ('49) found rudimentary nipples also in all males of the whale family.

In the monotremes, Owen ('32) noticed that mammary glands are present in both sexes. Later, Bresslau ('08) and ('12 b) in monotremes observed mammary glands in males which agree in shape and size with those of females. While nipples have been
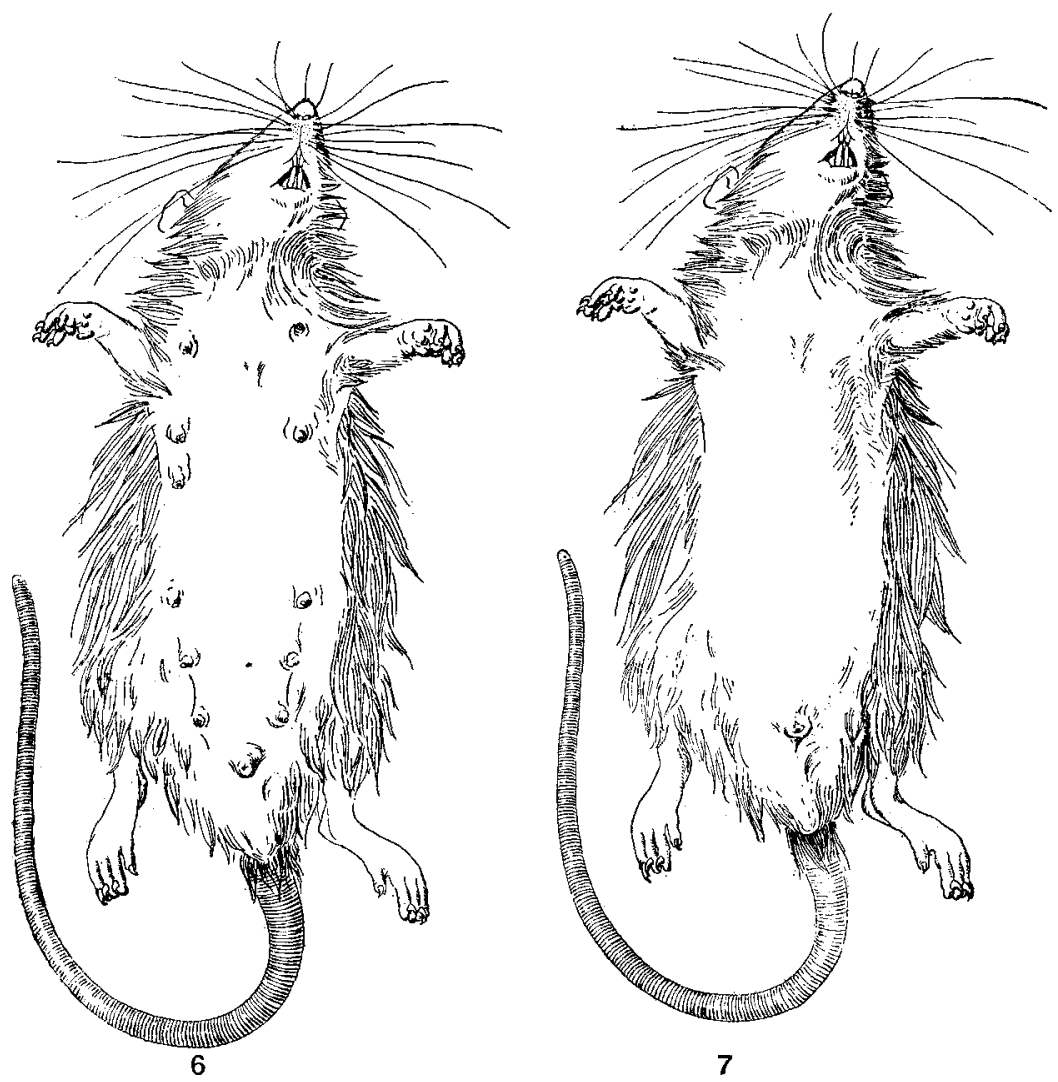

Fig. 6 Drawing of the ventral view of a young adult female albino rat in lactation. Hair removed from ventral wall. This specimen shows the absence of the left third thoracic gland. This is one of the most common variations in the number of nipples in the female.

Fig. 7 Drawing of the ventral view of a young adult male albino rat. Hair removed from ventral wall. No traces of mammary gland nipples are present. 
described in male marsupials by Laurent ('39) and Katz ('82), yet Leche ('97) and Bresslau ('12 b) believe that nipples do not ordinarily appear in male marsupials of the Australian species. According to Schickele ('99), Rapp ('52) states that generally no trace of a nipple appears in the males of Edentata.

Schickele ('99) in studying the number, position, and arrangement into groups of the nipples in the mouse, found it necessary to exclude adult males since in them he was never able macroscopically to recognize even rudimentary nipples with absolute certainty. In his macoscopic observations on adult rats he likewise found in males no nipples, not even rudiments. In one young male rat, however, he found 12 nipple anlages arranged the same as in female mice.

Our present knowledge therefore leads to the conclusion that in monotremes, the mammary glands of the two sexes reach about the same stage of development while in the higher forms of mammals the mammary glands of the male appear in a rudimentary condition. The existence of mammary glands in the males of some species of marsupials seems doubtful. In some forms (chiefly rodents) the, nipples in the males have entirely disappeared.

\section{Milk ducts}

In the present investigation the primary milk duct of the male albino rat was observed in eighteen day fetuses to resemble somewhat a large developing hair follicle. At nineteen days the duct has largely lost its resemblance to a hair follicle. It has grown in length, and in some glands presents secondary and tertiary ducts. The twenty day stage shows the ducts in approximately the same stage of development as in females of the same age. One difference, however, is in the appearance of a branch from the primary duct of males immediately beneath the corium. From birth to five weeks, the glands of the two sexes are about parallel in their development. At five weeks, the glands of the male begin to lag behind those of the female, the chief difference being that a smaller number of collateral branches appear on the ducts of the male. At nine weeks (about the time of puberty), the ducts 
of the female show a vast number of branches while those of the male are but slightly further developed than at five weeks. The marked contrast at nine weeks can be best appreciated by comparing figure 5 with figure 13 of an earlier paper (Myers, '16).

The resemblance of the early primary duct to a hair follicle may possibly have a phylogenetic significance. Bresslau ('02) found in marsupials that in the regions of the future mammary glands large hair anlages develop. From one side of each anlage a sebaceous gland buds off, while from the other side a milk duct develops. As time goes on the free end of the hair anlage and the sebaceous gland atrophy, but the milk duct develops very rapidly and retains its opening into the attached end of the hair follicle. In squirrels (Sciurus vulgaris), Bresslau ('12 c) found that the mammary gland anlage in both sexes divides into a medial and a lateral part; from the lateral part the milkducts develop, while from the medial part a bristle-like tactile hair develops, which in adult animals far surpasses in length and thickness the other hairs of the body.

Developing hairs and sebaceous glands closely related to the mammary gland anlage have also been described in man by Eggeling ('05), Brouha ('05) and Lustig ('16).

My figure 7 somewhat resembles Bresslau's figure 5 (Münchener Med. Woch., Jahrg., 59, S. 2794). In a later stage, it will be recalled, a branch was seen to spring from the side of the primary duct anlage near its attached end. It is possible that this branch may correspond with the sebaceous gland found in marsupials by Bresslau ('02) and in man by Lustig (see Lustig's fig. 10). Therefore the mammary gland anlage of the male rat at the time when it appears similar to a hair anlage, is perhaps repeating the conditions found in lower forms. The developing mammary gland of the female probably passes through a similar stage, but owing to the fact that it is much more highly specialized than the gland of the male it has more stages to pass through, and the earlier stages are doubtless passed over very rapidly.

The fact that after the fifth week of postnatal life the glands of the female are a little better developed than those of the 
male albino rat agrees with the findings of Kölliker ('79). He states that in human from one to ten years after birth the milk ducts and end buds increase only a little, branching somewhat more richly in the female than in the male sex. Krause ('06) also states that there is no essential difference in the glands of the two sexes at birth; the differences belong to later periods of life. Broman ('11) states that in the human the glands of the male do not develop after birth. In the rat, however, my figures 4 and 5 show that in the male there is considerable growth in the ducts after birth. This growth apparently merely keeps pace with the general body growth.

The tremendous differences which appear between the glands of the two sexes of rats about the ninth week correspond to the differences which have been described as occurring in the mammary gland of many species at about the time of puberty. The extent to which the mammary gland of the male develops is somewhat variable. At nine weeks as shown above most of the male rats show a small amount of branching of the ducts while others of the same age present a fairly dense arborization of milk ducts. The male albino rats examined after puberty by me show that slight development continues after that time.

While examining the mammary glands of many men, Cooper ('40) found that there is considerable individual variation. Ordinarily it is stated that the milk-ducts of males cease to develop after puberty and very soon pass through the stage of involution (McMurrich, '15, Jordan, '16, and many others).

Kölliker ('79) in men of twenty years, found mammary gland vesicles which were not found at about the time of puberty. Schenk also found end vesicles in the glands of men, but makes no mention of their age. It was not until about the thirtieth year that Kölliker found regressive metamorphosis beginning in the mammary glands of men. Furthermore, Merkel ('99) and Kerr ('16) state that occasionally at the time of puberty some swelling and soreness are experienced in the mammary glands of men. Therefore it must be concluded that the mammary glands in the male may show some (although slight) growth after puberty. 
In the descriptive part of this paper it was shown that the number of mammary glands is more variable in the male than in the female rat. In the female rat it has been pointed out by Schickele ('99), Henneberg ('00), Frank and Unger ('11) and Myers ('16) that an occasional supernumerary gland develops. The second or third thoracic glands may be lacking, but the others are always present in the female. The first and second inguinal glands as well as the second and third thoracic glands may be missing in the male. In all males examined the second inguinal gland when present is in a very rudimentary state.

As previously shown (Henneberg, '00, Myers, '16) in the female rat the second inguinal gland of each side is located laterocephalad to the urethral orifice. The ducts of this gland for the most part take a caudal direction from their epidermal attachment. Ultimately the branches extend caudad to the vagina for a considerable distance. In the male the second inguinal glands have approximately the same location. Caudal to the genital eminence, however, the integument becomes the outer wall of the scrotum. The skin of this region, being specialized so as to form a part of the scrotum, apparently forms a poor medium for the development and ramification of milk ducts.

The fact that the ducts corresponding to several of the mammary glands are often absent, together with the fact that the nipples are very rarely developed indicate that the mammary glands may be gradually disappearing in the male rat. On the other hand, the ducts present in the male so closely resemble those of the female until the time of puberty that it is easy to believe that the male milk glands were at one time functional, and with the proper stimulus might again develop into functional glands. Steinach ('12) found that the mammary glands of male guinea-pigs sometimes become functional after a pair of ovaries have been transplanted beneath the skin. Owing to the absence of nipples, Steinach regarded the rat as unfit for such experiments. 


\section{Occurrence of mammary glands in both sexes}

Several theories have been advanced regarding the occurrence of the mammary gland in both sexes. Barkow ('29) pointed out that in forms lower than mammals the brooding may be done by either the male or the female, or the two sexes may share equally in this work. Ruge ('95), Gegenbaur ('98) and Wilder ('08) believe that the mammary glands first appeared in the female and were later transmitted to the male. On the contrary, Haacke (93) thinks the mammary glands were transmitted from the male to the female.

A more logical view is supported by Paul ('84), Westling ('89), and Bresslau ('08, '10, and '12) who after carefully studying the mammary glands of lower mammals concluded that from its beginning the mammary gland was developed to the same extent in both sexes. The female gradually took the responsibility of nourishing the offspring and the mammary glands in the male became correspondingly nonfunctional.

The present work on the albino rat lends support to this theory. In the earlier fetal stages the mammary glands appear the same in both sexes. As development progresses the glands of the male lag behind those of the female, and no nipple is formed. When the adult condition is reached, the glands of the male possess no nipple and the milk ducts are in a somewhat rudimentary and variable state. Such a condition, together with the relations found in lower forms, lead one to conclude that the mammary glands were in ancestral forms equally developed in both sexes. The individual male rat in which Schickele ('99) found a complete set of nipples probably represents a reversion toward the earlier ancestral type in which the mammary glands of the two sexes were more nearly alike in structure.

\section{SUMMARY}

The results of the present study of the development of the mammary gland in the male rat may be summarized briefly as follows: 
1. While the sex glands are in the indifferent embryonal stage, there is no apparent difference between the anlages of the mammary glands in the two sexes.

2. In fetuses of eighteen days the mammary gland anlages of the male differ from those of the female in that they possess no mammary pit. In twenty day fetuses, when the nipple anlages are present in females, no trace of a nipple was observed in males. In fact, nipples apparently fail to develop in the male at all, including postnatal stages. Hair develops uniformly over the ventral surface of the body of the male leaving no macroscopic indication of a mammary gland area.

3. Like the nipple, the epithelial hood is also absent in male albino rats.

4. The primary milk duct in eighteen day male fetuses resembles a hair anlage. At twenty days the branches appear approximately as were found in females of the same age. Until about the fifth postnatal week the milk ducts of the two sexes are approximately parallel in their development. After the fifth week, the ducts of the female present more branches than those of the male. The difference is not very great, however, until the ninth week (age of puberty). Then the ducts of the female branch very profusely while the ducts of the male show but little change.

5. In the male the lumina of the milk ducts develop in the same manner and at about the same time as in the female.

6. The second inguinal gland of the male is very rudimentary and may be entirely lacking. This condition is evidently due to the development of the scrotum in the region which the second inguinal gland normally occupies.

7. The number of mammary glands is more variable in the male than in the female. No supernumerary glands were observed in the male. The second and third thoracic and the first and second inguinal glands are sometimes absent in the male. Usually not more than one or two of these glands are absent in a single individual. The other mammary glands were present in all rats examined. 


\section{LITERATURE CITED}

BARKow, H. C. L. 1829 Anatomisch-physiologische Untersuchungen, vorzüglich über das Schlagadersystem der Vögel. Meckel's Arch. f. Anat. u. Physiol.

Bresslad, E. 1902 a Beiträge zur Entwickelungsgeschichte der Mammarorgane bei den Beutelthieren. Zeitschrift f. Morphologie u. Anthropologie, Bd. 4.

$1902 \mathrm{~b}$ Weitere Untersuchungen über Ontogenie und Phylogenie des Mammarapparates der Säugetiere. Anat. Anz., Bd. 21.

1908 Die Entwickelung des Mammarapparates der Monotremen, Marsupialier und einiger Placentalier. I. Entwicklung und Ursprung des Mammarapparates von Echidna. Semon's Zoolog. Forschungsreisen, Bd. 4, Lieferung 5 .

1910 Der Mammarapparat (Entwicklung und Stammesgeschichte). Ergebn. d. Anat. u. Entw., Bd. 19.

1912 a Ueber Hyperthelie. Münchener Med. Wochenschr., Jahrg. 59, s. 2793-2795.

1912 b Die Entwickelung des Mammarapparates der Monotremen, Marsupialier und einiger Placentalier. II. Der Mammarapparat des erwachsenen Echidna-weibchens. Semon's Zoolog. Forschungsreisen, Bd. 4 (Jenaische Denkschr., Bd. 7).

1912 c Die Entwickelung des Mammarapparates der Monotremen, Marsupialier und einiger Placentalier. III. Entwickelung des Mammarapparates der Marsupialier, Insectivoren, Nagethiere, Carnivoren und Wiederkäuer.

Broman, Ivar 1911 Normale und abnorme Entwicklung des Menschen.

Brodra, Dr. 1905 Recherches sur les diverses phases du developpement et de l'activite de la mamelle. Archives de Biologie, T. 21.

Cooper, A. 1840 On the anatomy of the breast. London.

Eggeling, H. 1904 Ueber ein wichtiges Stadium in der Entwicklung der foetale Mamma beim Menschen. Anat. Anz., Bd. 24.

1905 Ueber die Drüsen des Warzenhofs beim Menschen. Jen. Zeitschr. f. Naturw., Bd. 39 .

Eschricht, 1849 Die nordischen Walthiere.

Frank, R. T., AND UNGER, A. 1911 An experimental study of the causes which produce the growth of the mammary gland. Archives of Internal Medicine, vol. 7 .

Gegenbaur, C. 1898 Vergleichende Anatomie der Wirbelthiere, Bd. 1.

HAACKE, W. 1885 On the marsupial ovum, the mammary pouch and the male milk glands of Echidna hystrix. Proc. of the Royal Society of London, vol. 38 .

1893 Ueber die Entstehung des Säugethieres. Biolog. Centralbl., Bd. 8.

Henneberg, Brunno 1900 Die erste Entwickelung der Mammarorgane bei der Ratte. Anat. Heft, Bd. 13.

JACKSON, C. M. 1912 On the recognition of sex through external characters in the young rat. Biological Bulletin, vol. 23 . 
Jordan, H. E., ANd Ferguson, J. 1916 A text-book of histology.

KaT2, O. 1882 Zur Kenntniss der Bauchdecke und der mit ihr verknüpften Organe bei den Beutelthieren. Zeitschr. f. wissensch. Zoolog., Bd. 36.

Kerr, A. T. 1916 The anatomy of the breast. Reference Handbook of the Medical Sciences, vol. 2, p. 445-458.

KöLliker, Th. 1879 Beiträge zur Kenntniss der Brustdrüse. Verh. d. phys. med. Ges. zu Würzburg, N. F., Bd. 14.

Krause, W. 1906 Die Entwickelung der Haut und ihrer Nebenorgane. Hertwig's Entwickelungslehre der Wirbeltiere, Bd. 2, Teil 1-2.

Lane-Claypon, Miss J. E., and Starling, E. H. 1906 An experimental enquiry into the factors which determine the growth and activity of the mammary glands. Proc. of the Royal Society, Series B, vol. 77 .

Ladrent, M. 1839 Recherches anatomiques et zoologiques sur les mammifères marsupiaux. Annales d'anatomie et de physiologie, T. 3.

Lustig, Hilda 1916 Zur Entwicklungsgeschichte der menschlichen Brustdrüse. Arehiv. f. mikr. Anat., Bd. 87.

McMurrich, J. P. 1915 The development of the human body. Fifth edition, Philadelphia.

Merkel, Fr. 1899 Handbuch der topographischen Anatomie, Bd. 2.

Myers, J. A. 1916 Studies on the mammary gland. I. The growth and distribution of the milk-ducts and the development of the nipple in the albino rat from birth to ten weeks of age. Am. Jour. Anat., vol. 19. (Abstract also published in the Anat. Rec., 1916, vol. 10, p. 230.)

1917 a A comparison of the mammary glands in male and female albino rats. (Abstract) Anat. Rec., vol. 11, p. 391.

$1917 \mathrm{~b}$ Studies on the mammary gland. II. The fetal development of the mammary gland in the female albino rat. Am. Jour. Anat. (in press).

Owen, R. 1832 a On the mammary glands of the Ornithorhynchus paradoxus. Philos. Transactions, vol. 122.

$1832 \mathrm{~b}$ On the mammary glands of Echidna hystrix. Proceed. Comm. Science and Corr. Zoolog. Soc., London, p. 2.

*Paul, H. 1884 Ueber Hautanpassung der Säugethiere, Jena, H. Pohle.

RAPP, 1852 Die Edentaten.

Ruge, G. Die Hautmusculatur der Monotremen und ihre Beziehungen zu dem Marsupial-und Mammarapparate. Semon's Zool. Forsehungsreisen, Bd. 2 (Jenaische Denkschriften, Bd. 5).

SCHICKELE, G. 1899 Beiträge zur Morphologie und Entwickelung der normalen und überzähligen Milchdrüsen. Zeitschrift f. Morphologie und Anthropologie, Bd. 1, Heft 3.

Schenk, S. L. Istologia normale dell'uomo (ital. transl. by Monti and Golgi).

SteINACH, E. 1912 Willkürliche Umwandlung von Säugetier-Männchen in Tiere mit ausgeprägt weiblichen. Geschlechtscharakteren und weiblicher Psyche. Archiv für die gesammte Physiologie (Pflüger's).

*Westling, Ch. 1889 Anatomische Untersuchungen über Echidna. Bih. Svensk. Akad. Handl., Stockholm, Bd. 15.

Wilder, H. H. 1909 History of the human body.

*'The original paper was not available for this work. 